ISSN-2199-353X

Online only at http://www.cahij.com/

\title{
TARİHİ İPEK YOLU GÜZERGÂHLARININ OLUŞUMU VE GELIŞMESİ
}

İbrahim ONAY*

\section{Özet}

Bu çalışma, dünya tarihi bakımından "İpek Yolu” diye tarif edilen ticari ağın, üzerinde hayat bulduğu coğrafi güzergâhları konu edinmektedir. Özetle, Çin'den başlayan İpek Yolu güzergâhları, batıya doğru yol alarak Asya'nın Batı bölümüne ulaşır ve Avrupa'ya kadar ulaşan ticari ağlarla bağlantılı hale gelir. Esasen bahsedilen bu ticari ağların tek bir güzergâh üzerinde olmadığı, tarihi süreç boyunca İpek Yolu üzerindeki coğrafi koşulların ve siyasal, askeri durumların neden olduğu farklı rotaların kullanıldığı bilinmektedir. Yine de esas itibariyle bu rotaların, Doğu'daki Çin başkentlerinden batı yönünde hareket ederek başlatıldığı, Kansu üzerinden Doğu Türkistan sahasına ve daha sonra Batı Türkistan sahasına uzandığı söylenebilir, buradan da çeşitli yollar vasıtasıyla Batı'ya doğru yolculuğuna devam eder. Dünyanın, Doğu ve Batı bölgeleri arasında karşılıklı olarak kullanılan bu ticari ağın, önemli kesişme noktalarından biri Baktriya bölgesidir. Burası Doğu ve Batı güzergâhlarının kesiştiği bir coğrafya olduğu gibi, Güney'de Hindistan'a ve Kuzey'de bozkırlara ulaşan ticari yolların da kavuştuğu bir nokta olmuştur. Bu nedenle İpek yolu güzergâhlarında Hint kökenli tacirlerin ve bunlara dair kültürel unsurların varlığı da doğaldır. İpek Yolu güzergâhları bakımından önemli kesişme noktalarından bir diğeri ise Batı Türkistan sahasında yer alan Maveraünnehir (Soğd sahası) olmuştur. Bu sahanın hem coğrafik konumunun sağladığ1 imkanlar hem de bu bölgenin yerleşik halkı olan Soğdların tacir kimlikleri, buranın İpek Yolu tarihinde anlamlı bir yer kazanmasına neden olmuştur. Bu ticari yollar, üzerinden geçtiği coğrafyaların kaderi bakımından da önemli etkiler yapmıştır. İpek Yolu güzergâhında bulunan; Kansu bölgesi, Turfan, Hami, Karaşar, Kuça, Hotan, Yarkent, Kaşgar, Semerkant, Buhara, Belh gibi şehirlerin iktisadi gelişimi, bu ticari yolların sağladığı imkanlarla doğrudan bağlantılıdır. Yine bu şehirlerde yaşanan dini ve kültürel gelişmeler konusunda da İpek Yolu'nun neden olduğu hareketlilik ve zenginliğin büyük payı olduğu bilinmektedir.

Anahtar Kelimeler: İpek Yolu, İpek, Tüccar, Rota, Soğd.

\section{FORMATION AND DEVELOPMENT OF HISTORICAL SILK ROAD ROUTES}

\begin{abstract}
This study is about the geographical routes on which the commercial network, which is defined as the "Silk Road" in world history, came to life and especially the Eastern part. In summary, Silk Road starting from China reach the Western part of Asia by traveling west and become connected with commercial networks reaching as far as Europe. In fact, it is known that these commercial networks are not on a single route, but different routes were used due to the geographical conditions and political and military situations on the Silk Road throughout
\end{abstract}

* Doç. Dr. Çankırı Karatekin Üniversitesi, Edebiyat Fakültesi, Tarih Bölümü Öğretim Üyesi. ibrahimonay06@hotmail.com 
ISSN-2199-353X

Online only at http://www.cahij.com/

the historical process. However, it can be said that these routes were started by moving west from the Chinese capitals in the East, stretched to the East Turkestan area via Kansu, and then to the West Turkestan area, from where it continued its journey to the West via various routes. One of the important intersection points of this commercial network, which is used in both directions between the Eastern and Western regions of the world, is the Bactria region. This was a geography where east and west routes intersected, as well as a point where commercial routes reaching India in the south and steppes in the north met. For this reason, the presence of Indian-origin merchants and cultural elements such as Buddhism is also natural in the history of the Silk Road. Another important intersection point on the Silk Road was Transoxiana (Sogdian area) located in the West Turkestan area. The advantages provided by the geographical location of this area and the merchant qualities of the Sogdians, the settled people of this region, caused this place to gain a significant place in the history of the Silk Road. Therefore, these trade routes had significant effects on the fate of the geographies they passed through. Located on the Silk Road; The economic development of Kansu region, and cities such as Turfan, Hami, Karaşar, Kuça, Hotan, Yarkent, Kashgar, Samarkand, Bukhara, Belh is directly related to the advantages provided by these trade routes. It is also known that the dynamism and wealth caused by the Silk Road had a great share in the religious and cultural developments experienced in these cities.

Key Words: Silk Road, Silk, Merchant, Route, Sogd.

\section{Giriş}

Dünya tarihi bakımından önemli hadiselerden biri İpek Yolu adı verilen ticari rotaların kullanılmasıdır. Bu ticari rotalar insanlık tarihi bakımından önemli gelişmelerin yaşanmasına imkan sağlamıştır. Bu ticari rotalar sayesinde Eski ve Orta Çağ'ın önemli dinleri ve inançdüşünce akımları seyahat ederek farklı coğrafyalara ulaşma imkanı bulmuş, maddi ve manevi pek çok unsur da buna dahil olmuştur. Bu rotalar üzerinde hakim olma mücadelesi, pek çok devletin kurulması ve yıkılmasına da zemin hazırlayan nedenler arasındadır.

Esasen, Doğu ve Batı dünyası arasında ticari ilişkilerin çok eski dönemlerden itibaren varlığı ve çeşitli aracılar vasıtasıyla yapıldığı zaten bilinmekteydi. Başlangıç noktası olarak Çin gösterilen ve Çin'den batıya doğru hareket eden bu ticari ağ ve ilişkilerin ne kadar eskiye gittiğini tam olarak belirtmek mümkün değildir. Bu konuda aracı rol oynayan bazı toplulukların varlığı ve rolleri konusunda çeşitli bilgiler ve değerlendirmeler de vardır. İpek Yolu adı ve ticari yolların bu isimle tarif edilir hale gelmesi ise 19. yüzyıl sonlarına doğru Alman bilim insanı Richthofen'in çalışmasına atfedilir. Bu tanımlamanın ortaya çıkması konusunda önemli süreçlerden biri, tarihte Çin açısından Batı tarafına dikkat çekilmesi ve gözlerin bu yöne çevrilmesine neden olan hadiselerin varlığıdır. Dolayısıyla rotaların İpek Yolu adı altında tarif edilmesine neden olan geçmiş tarihi süreç, ticari maksatlardan değil siyasi ve askeri gerekçelerden kaynaklanarak ortaya çıkmış görünmektedir.

Bu manada, tarihi İpek Yolu'nun açılması, bir Türk devleti olan Hun İmparatorluğu ile Çin'deki Han Devleti (M.Ö.206- M.S.220) arasındaki mücadelenin sonucudur. Bahsettiğimiz 
ISSN-2199-353X

Online only at http://www.cahij.com/

bu mücadelenin iktisadi nedenleri olduğu gibi, asıl gerekçenin siyasal ve askeri olduğunu değerlendirmek mümkündür. Cosmo'nun çalışmasında işaret ettiği üzere; Han ve Hun Devletleri arasındaki mücadele, Çinlilerin, Orta Asya'daki Hun liderliğine başkaldırmasına neden olmuştur. Bu durum ise Baron Von Richthofen'in tarifiyle "İpek Yolu'nun" açılmasına neden olmuştur (Cosmo, 2002: 718). Bu mücadelenin önemli hikâyelerinden biri, Çin adına, Batıda bulunan ülkelere ve şehirlere gönderilen casus bir elçinin varlığıyla ilgilidir. M.Ö. 139 yılında, dönemin Han İmparatoru Wu-ti tarafından görevlendirilen bu casus elçi, eskiden Kansu bölgesinde yaşadığı bilinen Yüeh-chihleri bulmak ve Hunlara karşı ittifak tesis etmek maksadıyla çıktığ 1 elçilik görevini 13 yıl içinde gerçekleştirebilmiş yine de asıl amacına ulaşamamıştır. Fakat onun dönüşte, imparatoruna sözlü veya yazılı olarak sunduğu rapor sonrası, Batı bölgelerindeki yabancı topluluklardan haberdar olan Çin, buralardaki Hun gücünü kırmaya ve kendi iktidarını buralara yaymaya karar vermiştir. Esasen casus elçi Chang Ch'ien'in yaptığı seyahatin en önemli sonuçlarından biri İpek Yolu'nun açılması olmuştur. Böylece, Batıya doğru yola çıkan elçiler ve ticari kervanlar, burada bulunan çeşitli ülkelerle ilişki tesis etmek, bu sayede Hun varlığı ve gücünü yok ederek, bu coğrafyalarda Çin varlığını sağlamayı amaç edinmişlerdir. Zamanla bu geliş gidişlerin karşılıklı hale gelerek artması ve gelişmesi İpek Yolu dediğimiz ticari rotaların oluşumu ve gelişimine imkan sağlamıştır.

\section{Kuzey Çin'in Coğrafi Durumu ve Hun -Han Mücadelesi}

İpek Yolu rotalarının oluşması bakımından başlangıç noktası olarak Çin’i almak doğru olur. Fakat Çin'in kuzey ve kuzey batı bölümünün Türk tarihinin ve kültürünün esaslı bir parçası olduğunu unutmamak gerekir. Kuzeydeki Bozkırlar ile Çin'in kuzey ve kuzeybatısındaki bölgeler, tarihte özellikle Türk ve kısmen diğer etnik toplulukların yaşam sahası olmuştur. ${ }^{1}$ Özellikle Kansu ve Ordos bölgesinin coğrafi konumu, bu topluluklar ile Çinlilerin ilişkileri bakımından da önem arz etmiştir. Hatta daha sonraları Çinliler tarafindan, büyük çoğunluğu Hsiung-nu, Hun, diye tarif edilen konargöçer nitelikli bu toplulukların Çin içlerine girmesine imkân vermemek için Çin Seddi inşasının gerçekleştiği bilinmektedir.

Gumilev'in işaret ettiği üzere; eski dönemlerde Çin ve Merkezi Asya sınırları Çin Seddi ile belirlenmiştir. Coğrafik koşulların da bunda etkisi vardır. Batıda Kan-su'da, Shan Shan eteklerinde yer alan vaha zinciri bu sınırı teşkil etmektedir. Huang-ho'nun kuzeye yönelen doğu kıvrımı Ordos bozkır ve sahrasını Shensi’nin alüvyonlu vadisinden ayırarak bilahare Shan-si'nin ormanlık vadisini bugünkü İç Moğolistan bozkırını dolaşarak tekrar nehre dökülür (Gumilev, 2013: 308). Çin'de Kuzeyin başlıca nehri Huang-ho'dur. Ona Sarı

\footnotetext{
${ }^{1}$ Eberhard'ın belirttiğine göre; geçmişte Çin'in Kuzey batısında Shensi ve Kansu'da bulunan kültür esas itibariyle bir avc1 kültürdür ve daha sonra çoban kültürüne dönüşmüştür. Bu toplulukların en önemli hayvanları sığır değil attır ve bu kültürün temsilcilerinin Türklerin ataları oldukları açıktır. Onlar, M.Ö. 3.binyılın ortalarında bile, sonraları taşıdıkları niteliklere sahip bulunuyorlardı. Esasen Türklerin ilk yurtlarının Shensi ve Kansu olduğu iddia edilemez fakat bu coğrafyanın Türklere ait bölgenin bir kenar parçası olduğu izlenimini vermektedir (Eberhard, 2007: 16-17) Ögel'de benzer düşüncededir (Bkz. Ögel, 2015a: 8).
} 
ISSN-2199-353X

\section{Online only at http://www.cahij.com/}

1rmak denmesinin nedeni, lös bölgesinden geçerken aldığı pek çok erimiş lösü de getirmesidir. Bu lösü kendi tabanına yığdığından zamanla nehrin yatağı yükselir ve taşkınlara neden olur (Eberhard, 2007: 2-3). Huang-ho hızlı akması nedeniyle kolay geçilir bir nehir değildir, fakat özellikle taşkınlar sırasında nehri geçitler üzerinden kat etmek çok zordur. $\mathrm{Bu}$ yüzden Ordos'u üç yönden çevreleyen büyük Huang-ho dirseği, bitişik çöller arasında bir ada görünümündedir. Kış ortasında nehir donduğu zaman ise Ordos, Büyük Bozkır tarafından gelen saldırılara karşı korumasız kalır (Gumilev, 2013: 307)

Esasen Hunlar, bu coğrafyalarda zaten var idiler. Pulleyblank'in işaret ettiği üzere; Çin'in Ch'in hanedanlığı tarafından birleştirilmesinden hemen sonra Hunlar tarih sahnesine çıktılar. Ch'in hanedanlığı imparatorunun ilk icraatı da Hunları yaşadıkları bölgeden sürmekti. O sırada Hunlar Sarı Nehrin güneyinde Ordos bölgesinde yaşamaktaydılar. Çinliler, onları Sarı Nehrin kuzeyine sürdü böylece kuzey sınırlarını korumak istediler. Bu imparator, büyük Çin duvarını da inşa ederek ünlenmişti. Gerçekte büyük duvarın Sarı Nehrin büyük kemerindeki duvarları Hu'lara karşı Chao'lar zamanında yapılmıştı. Bu nedenle Hunların uzun süredir Ordos bölgesinde yaşadıklarını düşünmek mümkündür (Pulleyblank, 1995: 419). Dolayısıyla Ordos bölgesinin de tıpkı Kansu bölgesi gibi, Hun coğrafyasının doğal bir uzantıs1 olduğunu söylemek mümkündür. Hun tarihi bakımından, bu bölgelerin kaybedilip yeniden ele geçirilmesi tekraren yaşanmış süreçlerdir. Yine Çin devletleri ile olan askeri ve siyasi çatışmalar da bu alanlarla ilgili olmuştur. Beckwith'in işaret ettiği üzere; kaynaklarda tekrar tekrar vurgulandığı gibi, Bozkırlıların Çin'e yaptığı akınların esas maksadı, sınır bölgelerinde serbest ticareti yeniden sağlamaktı, üstelik bu sınır bölgeleri eskiden bozkırlıların otlaklarıydı ve ellerinden alınmıştı (Beckwith, 2011: 24). Dolayısıyla Ordos sahası, coğrafik koşulların neden olduğu iktisadi, askeri gerekçelerle Türk ve Çinlilerin mücadele ettiği bir bölgeydi.

Bahsettiğimiz bu coğrafi ve iktisadi prensiplerin Çin açısından diğer yerleşim yerleri içinde etkili olduğunu söylemek mümkündür. Eberhard'ın belirttiği üzere; Ordos'un güneyi, Sarı Irmağın bir kolu olan Wei Nehri'nin, nehir bölgesine aittir. Wei Çin'in en eski kültür merkezlerinden biri olup aynı adı taşıyan bereketli bir ovadan geçmektedir. Nehir, Çin tarihinde iktisadi ve siyasi bakımdan önemlidir, zira kervan yolu Wei nehri boyunca doğuya gider. Bu yüzden Wei'nin aşağı kolu üzerinde bulunan, uzun zamanlar Çin'in başkenti olmuş olan Ch'ang-an ve Lo-yang şehirleri transit ticaretin merkezleri durumunda olmuştur (Eberhard, 2007: 4). Dolayısıyla Çin'in siyasi merkezleri de iktisadi prensipler hesaba katılarak seçilmiş görünmektedir.

Çin açısından kuzey tarafı Hun ve diğer konargöçer topluluklarla kapalı olduğundan güneyde ise bir yol henüz bilinmediği için, dış dünyayla iletişim sadece Batı tarafından sağlanabilirdi. Fakat Ögel'in belirttiği üzere; Batıdan, Çin'e gelen ticaret yolları hakkında kesin bilgilerimiz var olmakla birlikte, bahsettiğimiz eski dönemde ve hatta daha sonra bile, Çin'in batıya açılan kapıları Çinlilerin elinde değildi. Çünkü coğrafi olarak; Tanrı dağları, Doğu Türkistan ve Kansu üzerinden gelen ticaret yolları, Orta Asya kavimlerinin yurtları durumunda idi. Bu kavimler Çin'in içindeki Wei ırmağına kadar iniyorlardı. Esasen henüz 
ISSN-2199-353X

Online only at http://www.cahij.com/

M.Ö. 461 yılından sonra Çinlilerin ilgileri, bu kapıya doğru yönelmiş fakat Çin sınırlarını aşamamıştır, çünkü Kansu bölgesi Hun çağında bile Hunların bir yurdu durumunda idi (Ögel, 2015b: 48).

\section{İpek Yolu Rotaları}

Çin kaynakları bakımından, eskiden İpek Yolu tarifi bulunmadığından bu ticari yolların bir bölümünün üzerinde bulunduğu bölgeler ve ülkeler hakkında bilgi verirken yapılan tarifin Hsi yü olduğu anlaşılmaktadır. Kırilen'in belirttiği üzere; Çin kaynakları, eskiden Batı Bölgeleri (Xiyu, Hsi-yü) adıyla bilinen ve Çin'in batısında kalan bütün ülke ve bölgeleri kapsayan, antik dönemde "Otuzaltı Ülke" adıyla anılan bir coğrafya hakkında bilgi vermektedirler. Bu coğrafi alan ise; bugünkü Doğu Türkistan (Xinjiang) Otonom bölgesiyle, Türk Cumhuriyetlerinin, Afganistan ve Pakistan'ın da bulunduğu alanları içermektedir (Kırilen, 2015: 23). ${ }^{2}$ Çin'de Han Hanedanlığ döneminde tarif edilen rotalar ise şu şekildedir. Güney rotası; Lobnor dan başlayan ve Güney Dağları'nın kuzey tarafı boyunca devam ederek Yarkent'e ulaşmaktadır. Buradan da Vahşan vadisi yoluyla Ta-Yüeh-chihlere veya Belh'e kadar uzanmaktadır. Kuzey rotası ise Turfan'dan başlayarak T'ien Shan dağlarının güney ayağı boyunca Kaşgar'a uzanmaktadır, Terek vasıtasıyla Fergana'ya ve Kırgız steplerine ve Hazar Denizi'nin kuzeyindeki bölgeye veya Soğdiyana bölgesine ulaşmaktadır. Sonraki Han Hanedanlığı zamanında da bu rota değişmemiştir (Shiratori, 1957: 12-13). ${ }^{3}$

İpek Yolu rotaları hakkında bilgi veren Batılı kaynaklar da vardır. Tezcan'ın çalışmasında belirttiği üzere; İpek Yolu, sadece tek bir yol değil, bir yollar ağıdır. İpek Yolu'nun üzerinden geçtiği yolları araştırma işini M.S. I. yy.' da yaşayan Tyrli Marinus'tan öğrenmekteyiz. Onun verdiği bilgilere göre, Maes Titianus, bu yolu araştırmak için Doğu’ya adamlarını göndermişti. $\mathrm{Bu}$ insanlar, deniz yoluyla Kuşhanların ülkesine gidemeyeceklerinden kara yolunu kullanarak Part ülkesinden geçmişler ve Orta Asya'ya gitmişlerdi. Bu kimselerin getirdiği bilgiler ise daha sonra, MS II. yy. ortalarında eserini yazmış olan coğrafyacı Claudius Ptolemaios tarafından da kayda geçirilmişti. Bu kaynaklardan öğrendiğimiz bilgiler ve daha sonra Richthofen'in tarifine göre İpek Yolu, dört

\footnotetext{
2Esasen Çin kaynakları bakımından "Batı Bölgeleri” ifadesinin değişen bir coğrafik nitelik taşıdığı anlaşılmaktadır. Ekrem'in çalışmasında belirttiğine göre; Hsi-yü siyasi idare bölge adı, Han Hanedanlığı döneminde bugünkü Doğu Türkistan'ın güney bölgelerini ifade etmekle birlikte bu adın Han Hanedanlığının Orta Asya'yı ele geçirme durumuna göre genişlediği veya daraldığı görülmektedir. Bu tarif bazen Doğu Türkistan'ı gösterirken, bazen Batı Türkistan'ın bir bölümünü de içine almaktadır (Ekrem, 2012: 21).

${ }^{3}$ Shiratori'nin çalışmasında belirttiği üzere; Han-shu'nun batı bölgeleri kayıtlarındaki rotalar: Han Shu, (Hsi Yu-chüan): "Hsiyü için iki rota vardır (Batı Bölgeleri): Yümen'den ve Yang-kuandan. Birisi Lob-nor'dan (Shan shan) hareket ettiğinde Nanshan'ın kuzey tarafi boyunca ( güney dağları) ve nehir boyunca, batıya doğru Yarkent'e (Sha-ch'e) ulaşır. Burası Nan-tao olarak adlandırılır. (Güney rota). Güney rota batıya doğru uzadığında ve Tsung-lin'i geçtiğinde (Pamirler), Ta-yüeh-shih'e ve An -hsi'ye uzanır. Diğeri Ch'e-shih den (Turfan) ve Ch'ien-wang-t'ing'den, Pei-shan vasıtasıyla (Dağların kuzeyinden) nehir boyunca giderek batıya doğru Kaşgar'a ulaşır. Burası Pei-tao olarak adlandırılır. (Kuzey Rota). Kuzey rotası batıya doğru uzadığında Ts'ung-ling'leri geçtiğinde, Fergana'ya, Kırgız steplerine ve Yen-ts'ai ye uzanmaktadır (Shiratori, 1957: 12). Sonraki dönem diğer Çin kaynakları olan Pei-shih ve Wei-shu'da yer alan Hsi-yü-chuan; "Bu rotalar Hsi-yü için (Batı Bölgeleri) orjinal olarak iki tane idi. Daha sonraları 4 oldu. Yümen'den geçerek Liu-sha'ya ve batıya doğru 2000 li gidildiğinde Lobnor'a kadar, bu birinci rota. Yü-men den, Liu-sha geçilerek ve kuzeye doğru 2200 li kadar gidildiğinde Turfan'a kadar, bu diğer rotayı oluşturur. Yarkent'ten batı'ya doğru 100 li karar gidildiğinde Ts'ung-ling, Tsung-ling'den batıya doğru 1300 li Ch'ieh-pei ye kadar. Bu diğer bir rotayı oluşturur. Yarkent’ten güneybatıya 500 li ve Tsung-ling'leri geçerek, güneybatıya doğru 1300 li gidildiğinde Gilgit. Bu da en son rotadır (Shiratori, 1957: 12-13).
} 
ISSN-2199-353X

Online only at http://www.cahij.com/

ana yola ve ikinci derecede bazı alt kollara ayrılmaktadır. Esasen yolun Batı ve Doğu olmak üzere başlıca iki ana bölgeye ayrıldığı, Batıdan ve Doğudan gelen yolların ise, bugünkü Doğu Türkistan'ın batısında, Pamir eteklerinde bir yerde (Taş-Kurgan) kesiştiği anlaşılmaktadır. Bu kesişme noktasında, Doğu ve Batı bölgelerinden gelen ticari malların değiş tokuş edildiği anlaşılmaktadır (Tezcan, 2014: 97-98). Vaissiere'nin işaret ettiği üzere; Ptolemaios'un “Coğrafya"sına göre; (M.S.150) Roma imparatorluğundan gelen tüccarlar, Baktriya üzerinden dağları geçerek Çin'e gidiyorlardı (Vaissiere, 2005: 35-36). Han dönemi kayıtlarının Doğu ve Batı arasındaki ilişkiyi ortaya koymak konusunda ne kadar değerli olduğunu belirten Shiratori, bu dönem Batı dünyasında bu iletişimden bahseden önemli bir kaynak Ptolemaues'un Geography (Geographike Syntaxis) eserinin kusurlu ve yanlış pek çok tarafı olduğunu belirtmektedir. Bununla birlikte Ptolemaues aynı bölge hakkında İpek Yolu'nun gelişimi sayesinde kültürel ve coğrafik bilgiler elde etmiş ve bunları eserinde anlatmıştır (Shiratori, 1957: 1) $)^{4}$.

Genel olarak, bir bütün olarak değerlendirdiğinde Çin'den başlattığımız İpek Yolu'nu; ana birkaç yol ve çeşitli tali yollardan oluşan büyük bir ticari ağ olarak tarif edebiliriz. Uzun asırlar boyunca bu yollar üzerinde gerçekleşen; siyasal değişimler, askeri mücadeleler ve coğrafik değişimler yolların tercih edilip edilmemesi konusuna tesir etmiştir. Bu nedenle, her dönem için geçerli olmak üzere kesin ve değişmez tek bir ticari rota tarif etmek mümkün değildir. Batıya doğru giden bu rotaları en genel ve en yoğun kullanılma durumuna tarif etmek mümkündür.

\section{Kansu ve Çin}

İpek Yolu rotaları bakımından Çin'den batıya doğru hareket etmek için yapılacak yolculuklarda başlıca güzergâh Kansu üzerinden geçmektedir.

Eski Çağ boyunca Kansu bölgesi Türk ve diğer konargöçer toplulukların doğal yaşam sahası olmuştu. Türk kökenli toplulukların veya diğer konar göçer halkların bu bölgede hakim olduğu bilinmekteydi. Fakat Çin merkezlerinden Batıya doğru hareket edecek kervanlar veya kimseler için gidilecek başlica güzergâh da Kansu'dan geçmekteydi Ögel'in belirttiği gibi; Kansu, Çin'in hemen yanı başında bulunmaktaydı ve bir "Batı Kapısı" idi. Çinliler buraya Ho-hsi yani "Sarı ırmağın batısı” diyorlardı (Ögel, 2015a: 427). Eberhard'ın işaret ettiği üzere; Kansu; Çin'in en kuzey batısında bulunan, Çin'den Türkistan'a kadar uzanan ince, dar

\footnotetext{
${ }^{4}$ Shiratori'ye göre; Taşkurgan konusundaki tarihi tartışmalardan birisi buranın Ptolemaeus'un eserinde bahsettiği "Stone tower" adındaki yer olup olmadığı hakkında idi. Ptolemaeus yaklaşık olarak ikinci yüzyılın ortalarında yaşamış bir adamdı. Onun eserindeki bilgiler, çağdaşı olan Coğrafyacı Marınus'un çalışmalarını esas almaktaydı. Ptolemaeus eserinde Marınus'dan aldığı bilgilere atıf yapar. Marınus ise bu bilgileri Maes veya Tıtanus'dan elde etmiş̧ir. Bu ikisi Makedonyalı tüccarlardır. Bu rotanın bir parçasını şahsen geçen Maes geri kalanını kendisi ve katibi ile tamamlamış ve bu yolculuğu Seres'e onun için ipek satın almak için yapmıştır. Marinus'un ise tam olarak ne zaman yaşadığı bilinmemektedir. Bilim adamlarından Tomascheck, onu yaklaşık M.S.80-100 yıllarına koyarken, Marquert, daha eski bir tarihte İmparator Nero çağında (M.S. 54-68 yılları arasında) yaşadığını belirtir. Hermann ve Honigmann ise yaklaşık olarak M.S. 110 yııllarına koymaktadır. Özetle şunu söyleyebiliriz ki bahsedilen Marinus, Milattan sonra birinci yüzyılın son yarısı ile ikinci yüzyılın başlarında yaşamış olmalıdır. Onun verdiği bilgiler ile diğer bilgiler Ptolemaeus tarafından mukayese edilmiştir. Ptolemeus'un verdiği bilgilere göre: Baktriya'dan, Komedo1 Platosuna akan yol, "Stone Tower'ı" geçerek gider ki burası Doğu ve Batı arasındaki bağlantıyı sağlayan ana yollardan birisidir. Bu nedenle Doğu ve Batı'nın tüccarları başlıca bağlantıyı burada gerçekleştirirlerdi. Ptolemaeus'un verdiği bilgilerde bu rotanın Stone Tower'den hangi yönde devam ettiği konusu ise belirsizdir (Shiratori, 1957: 2).
} 
ISSN-2199-353X

Online only at http://www.cahij.com/

bir yer durumundaydı. Burası Kuzeyde Gobi çölü ile güneyde Güney Tibet dağlarıyla sınırlanmıştı. Fakat çölle, dağların arasındaki dar bölgede bulunduğundan ziraat için de elverişli durumdaydı. Ayrıca burası Çin ile Batı Asya arasında bulunan büyük kervan yolunun başlangıcı durumundaydı. Bu sebepten, bu eyaletin Çin için daima stratejik ve iktisadi önemi olmuştur (Eberhard, 2007: 4). Bu nedenle, tarihte Çin bu bölgeyi Hunlardan almak konusunda son derece kararlı olmuştu. ${ }^{5}$

Çin'in Batı kapısı sayılan ve M.Ö. 121-119 yılları arasında Hunların elinden alınan Kansu' $\mathrm{da}^{6}$, Çin tarafından il ve ilçe teşkilatı kurularak yavaş yavaş iskan yoluna gidilmiştir. Böylece Hunların eski yurtları ve toprakları olan Kansu, bir Çin arazisi haline gelecekti. Hunlar bu çağa kadar, Tibetlileri de kontrol altında tutarak, Çin'e batıdan çeşitli baskılar yapmışlardı. Çinlilerin Kansu'da yaptıkları bu yeni düzenlemeler ile Hunlar ve Tibetliler arasında bir tampon bölgesi de meydana gelmiş olacaktı (Ögel, 2015b: 67) Böylece Kansu'daki bu yol, Tibetlilerle Gobi'de yaşayan kavimleri (Türkler yahut Moğollar) birbirinden ayırdığından, bu toplulukların Çin'e karşı işbirliği yapmalarına da engel oluyordu (Eberhard, 2007: 4). Ho hsi koridorunun ele geçirilmesinden sonra Han yönetimi, Wuwei ve Jiuquan da komutanlıklar tesis etti. Tun huang bölgesi Jiuquan komutanlığına bağlıydı. 10 yıl sonra Wuwei ve Jiuquan komutanlıkları bölündü ve Chang ye ve Tun huang komutanlıkları da tesis edildi. Burası Merkezi Çin'in kapısı oldu. Han yönetimi, Ho-hsi' den Merkezi Asya'dan kadar olan rotayı korumak için çalıştı. Bu önlemler "(Hsi Yu-chüan):" da yani Han shu da "Dört kumandanlığın Kurulması" ve "İki Geçidin Ele Geçirilmesi” şeklinde anlatılır (Xinjiang, 2013: 20-21).

\section{Tun Huang}

Burası önceki Han Hanedanlığından itibaren Çinlilerin yönetimi altında bir bölge olmuştu. Esasen Tun huang vahası batı Kansu Koridorunun batısında bulunmaktadır. Buranın yerleşikleri Tibet ya da Türk atalardan gelen ve Çinlilerle karışmış olan yabancılardı (Bielenstein, 2005: 466) Stein'in belirttiği gibi; Han Devleti zamanında Tun huang, Çin için sınırdaki son vaha idi. Büyük çöl yolculuğuna başlayacaklar için başlama noktası ve doğu köprübaşı durumunda idi (Stein, 1919: 267). Onun bu stratejik önemi İpek Yolu sayesinde zenginleşmesine ve gelişmesine neden olmuştur. Uhlig'in ifade ettiği gibi; bin yıl boyunca Tun huang, Çin'in batı ticaretinin can damarı olmuştur. Bu nedenle olağanüstü önem taşıyan

\footnotetext{
${ }^{5}$ Geçmişten itibaren çeşitli konargöçer halkların doğal yaşam sahası olan bu bölgede, Asya Hun Devleti zamanına yaklaşıldığında bir takım siyasal değişimlerin yaşandığı anlaşılmaktadır. Zira Ögel'in çalışmasında ifade ettiği üzere; Hun Şanyü'sü Mete'den önce buraları Yüeh-chih Devleti'nin toprakları idi. Her ikisi de hayvancı olan bu kavimler arasına soy bakımından bir sınır koymak çok güçtür (Ögel, 2015a: 427) Ho hsi, Çin ve Batı bölgeleri arasındaki anayolun üzerinde bulunurdu. Bu stratejik önemine binaen Mete Şanyü, Yüeh-chih ve Wusunlar üzerine saldırmıştı. Onun oğlu Lao Shang Şanyü de onlara saldırarak bu kabilelerin uzağa, batıya doğru sürülmesine neden olmuştu. Ho-hsi bölgesinin ele geçirilmesi ve bir yandan Tien Shan dağlarının güneyindeki Ch'e-shih'in ele geçirilmesiyle birlikte Hunlar ilk defa Tarim Basin bölgesinde surlarla çevrili duvarlı kentleri kendi idareleri altına almayı başarmışlardı (Shiratori, 1930: 5-6). Böylece Yüehchihlerden kurtarılan Kansu ve batıda bulunan birtakım topraklar -en azından Balkaş, belki de Aral Gölünün kıyısına kadar uzanan bütün bozkırlar Hunların eline geçmişti. Hunlar bu sıralar Tarım havzasındaki, hatta Soğd ülkesindeki vahalara kadar dayanmışlar, hatta daha da içerilere kadar da gitmişlerdi. Hunların iktisaden güçlenmelerinin asıl nedeni de budur (Roux, 2000: 59).

${ }^{6}$ M.Ö. 119 da Çinliler büyük kayıplar verdiler fakat Hunları Kansu'dan atmayı başardılar ve buralara köylüleri yerleştirdiler (Eberhard, 2007: 95).
} 
ISSN-2199-353X

\section{Online only at http://www.cahij.com/}

bir kentti. Üstelik buradan Çin'in başkentlerine uzanan yol, Batı ile arasındaki yolla hemen hemen aynı mesafedeydi (Uhlig, 2000: 227). Dolayısıyla burası zenginliğini yapılan seyahatlere borçluydu, çünkü bu yol İpek Yolu rotasının tam üzerinde bulunmaktaydı (Bielenstein, 2005: 466).

Bu stratejik önem burayı, İpek Yolu'nun neden olduğu din ve düşünce akımlarından en fazla etkilenen yerlerden biri haline getirmişti. Baykuzu'nun belirttiği üzere; Han Hanedanlığı (M.Ö. 206 - M.S. 220) zamanında kurulmuş Tun huang şehri zamanla Budizm'in yaşadığı en parlak merkezlerinden biri olmuş, yüzyıllar boyunca birçok hanedanlık tarafindan burada binlerce Budist mağaraları inşa ettirilmiştir (Baykuzu, 2007: 195). Esasen Xinru'nun belirttiği gibi; Merkezi Asya'nın vahalarında farklı pek çok dini gelenek var olmuştur. Budizm ise İpek Yolu üzerinde dominant din olmuş ve onun kurumları Batı Hindistan'dan Çine uzanan tüm yollar boyunca var olmuştur. Budist anıtlar ve Budist manastırlar, pek çok seyahat edeni de misafir etmiştir. İslami fetihler, Hindistan'ın ve Merkezi Asya'nın bazı parçalarını sekizinci yüzyılda ele geçirmeden önce, Budist kuruluşlar İpek Yolu'nun Doğu Avrasya bölümünde altyapı kurmuştur. Budist altyapının yanında, İpek yolunun canlılığı, en prestijli ve en yaygın ticari ürün olan ipeğin ticareti sayesinde gelişmeye devam etmiştir. Yaşanan politik değişimler ipek talebini asla boğmamış, sadece talebin yapısını ve ipek pazarlarının tedarik yollarını etkilemiştir (Xinru, 2010: 72).

\section{Lou-lan}

Çalışmamızda belirttiğimiz üzere; İpek Yolu dediğimiz ticari rotaların gelişmesinde Çin'in Batı'ya hâkim olma çabasının etkisi bulunmaktaydı. Tun huang bölgesinden yani Kansu'dan dışarı çıkıldığında izlenebilecek rotalardan biri Lou-lan üzerinden geçmekteydi.

Esasen Lou-lan Doğu Türkistan'ın Çin'e açılan kapısı konumundaydı. Hunların eski çağında Lobnor denilen, tuzlu göl veya bataklığın kıyılarında kurulmuştu (Ögel, 2015b: 23). Hun dönemiyle ilgili olarak Lou-lan ve Turfan bölgesinde bulunan Ku-shih (Ch'e-shih), Bat1 ülkelerine seyahat edecekler için hareket noktalarının başlangıç noktalarında konumlanmışlardı (Enoki. 1963: 126). ${ }^{7}$ Anlaşılan bu iki devlet de Hun çağından itibaren Çin'in batıya açılan siyasetinin ve stratejisinin önemli bir yerinde bulunmaktaydı. Üstelik Stein'in belirttiği gibi; Çin ticari ve askeri girişimi, Tarim Basin bölgesine doğru devam ettiği sürece, hareket batı yönünde düz bir çizgide toprak ve tuzlu kurumuş Lop Denizine ve Loulan yerleşimine doğru olacaktı (Stein, 1919: 267). ${ }^{8}$ Zira Ögel'in işaret ettiği üzere; Lou-lan, Doğu Türkistan'ın doğusunda çöllerin ve tuzlu bataklıkların arasında kalmış bir yerdir, ancak Çin'den batıya doğru giden İpek Yolu ile diğer ticaret yolları Lou-lan'dan geçmek zorundadır.

\footnotetext{
${ }^{7} \mathrm{Bu}$ devletler Han elçilerine son derece ciddi kayıplar verdiriyorlar, onları ve maiyetlerini soyuyorlardı. Diğer taraftan Hunlarla gizlice anlaşıyorlar ve Hun askerleri Han elçilerinin yolunu kesiyorlardı. Bu nedenle Wu-Ti, Yüan-feng döneminin 3. Yılında (M.Ö. 108 ) Ch'ao P'o-nu'yu bu devletler üzerine gönderdi ve Ch'ao Po-nu bunları hem Lou-lan hem Che-shih'i yenerek Han'a tabi hale getirdi. Lou-lan Han tarafindan ele geçirilince, Hunlar asker göndererek yeniden Lou-lan'1 ele geçirdiler. Böylece Lou-lan hem Han'a hem Hun'a rehin göndererek her ikisine de haraç ödemek zorunda kaldı. O zamanlardan beri Lou-lan bazen Hunların gizli hareketleri hakkında Han'a bilgi veriyor veya Han elçilerinin öldürülmesi ve önünün kesilmesi konusunda Hunlar namına çalışıyorlardı (Enoki, 1963: 126).

${ }^{8}$ Stein, bunu 1914-1915 yıllarındaki Lop çölündeki keşiflerinde gösterdiğini belirtmektedir (Stein, 1919: 267).
} 
ISSN-2199-353X

Online only at http://www.cahij.com/

Kervanlar, buradan çıktıktan sonra büyük çöllerin içinden geçeceklerinden, su ve yiyecek gibi ihtiyaçlarını Lou-lan'dan alırlardı (Ögel, 2015a:319).

Fakat buradaki şehirler sonradan, suların akıntılarına göre yer değiştirmiştir (Ögel, 2015b: 23). Burada bulunan bataklıklı tuzlu göle Lobnor adı verilirdi, sonradan bu şehre veya şehirler bölgesine Şanşan adı verilmiştir (Ögel, 2015a: 319). Örneğin milattan sonra 3. yüzyıldan sonra Lou-lan çöl olmaya terk edildi ve böylece su isteyenler için direkt rota daha zor ve imkânsız hale geldi. Yine de Merkezi Asya ile olan ilişki çökmeden kurtuldu ve hayatta kalabildi. Batı bölgelerindeki Çin politikası, rotanın tamamıyla değiştirilmesi ile Peishan "Gobi" den Hami ye oldu (Stein, 1919: 267).

\section{Hami}

Hami bölgesi, Orta Asya ve Çin arasında çok değerli bir geçit yeridir. Üç dağ arasında uzayan bu büyük vaha bölgesi, doğu ve batıdan çöllerle çevrilmiştir. Bundan dolayı Hami, doğu ve batıdan gelen kervanlar ile orduların dinlenip, azıklarını tamamladıkları bir yer idi. Bunun için Hami'de geçmişte hem Hunlar hem de Çinliler ziraati geliştirme zorunda kalmışlardı (Ögel, 2015b: 282). Daha sonraki tarihi süreçte de Hami bu önemini korudu. Stein'in ifade ettiği gibi; Hami, sulama kolaylıkları nedeniyle, özellikle de onun yakınlarındaki Karlık- Dağ' dan gelen kar suyu sayesinde, bütün tarihi zamanlar boyunca zirai üretim için uygun bir yer ve doğal Pazar yeri olmuştur. Yine herhangi bir trafik, çölü güneydoğuya doğru geçmek istese burayı kullanması gerekmektedir (Stein, 1919: 267). Bu nedenle Hami bölgesi Çin'den çıkacak veya Çin'e ulaşacak tüccarlar için önemli bir üs bölgesi olmuştur. Dolayısıyla Mori'nin çalışmasında belirttiği üzere; I-wu'nun (Hami= kumul) Çin açısından çölü geçip, Tien-shan'ın doğu ucuna varmak isteyenler için bir kara limanı olmakla kalmayıp, Tien-shan sıradağı boyunca gelen İranlı tüccarlar açısından da Çin ya da Moğolistan'a açılan en doğudaki üs konumunda olduğu bilinmektedir (Mori, 1984: $342)$.

\section{Turfan}

Kuzey İpek Yolu rotasından batıya doğru, Tarım bölgesine doğru hareket ettiğinizde Hami'den sonraki ilk büyük vaha Turfan'dır. Han zamanında Ch'e-shih diye adlandırılan bu devlet daha sonra Kao-ch'ang diye isimlendirilmiştir (Bielenstein, 2005: 293).

Hunlar için bu bölgenin son derece önemli olduğu bilinmektedir. Shiratori'nin ifade ettiği üzere; geçmişte Hunlar bakımından, Ho-hsi bölgesinin ele geçirilmesi ve bir yandan Tien Shan dağlarının güneyindeki Ch'e-shih'in ele geçirilmesiyle Hunlar, ilk defa Tarim Basin bölgesinde surlarla çevrili duvarlı kentleri kendi idareleri altına almayı başarmışlardı. Çinliler tarafından büyük duvarların yapılmasından sonra, Hunlar istedikleri zaman Huang-ho (Sarı nehir) bölgesini kolayca istila ve Çinlileri yağmalama imkânından mahrum kalmışlardı. Fakat şimdi duvarlarla çevrili şehirlerde ve çevresinde yaşayan yerleşikleri kontrol altına almak İmparatorluğun devamı için oldukça önemliydi (Shiratori, 1930: 5-6). Hun döneminde, Turfan Kralı da bir "tüccar kenti” şehrinin Kralı olduğundan iç politikasına değil; daha çok Çin ile Hunlar arasında denge siyaseti izlemeye vermişti Turfan, büyük ticaret yollarının 
ISSN-2199-353X

Online only at http://www.cahij.com/

geçtiği, bir ziraat ve ticaret merkeziydi. (Ögel, 2015b: 19). Daha sonra burada burada Çinliler tarafindan Kao-ch'ang komutanlığı kurulmuştur. Guangda'ya göre; Kao-ch'ang komutanlığı döneminde bölgenin askeri ve politik durumu Han ve Wei döneminde olduğu gibiydi. Kaoch'ang yönetimleri sulama ağı konusunda son derece başarılı olmuşlar ve buna hayati önem vermişlerdi (Guangda ve Xinjiang, 1998: 16). Gök Türkler döneminde Türkler, Turfan'ın Hun dönemindeki eski statüsüne dokunmamışlar, onu kendi Kralı ile baş başa bırakarak yararlanmaya dikkat etmişlerdi (Ögel, 2015b: 19). Zira Gök-Türk çağında Turfan, göçebelerin buğday ve giyim ihtiyaçlarını karşılıyordu. Hatta Turfan bu bakımdan öylesine zengindi ki Çin'e dahi mal gönderebiliyordu (Gumilev, 2004: 197-198)

Turfan İpek Yolu ticareti sayesinde pek çok tüccar topluluğu kendine çekmeyi başardı. Xinru'nun belirttiği üzere; İpek Yolu üzerinde taşınan ürünler, mallar arasında Pers mallarına yüksek talep edilirken, bunlarla ilgilenenler muhtemelen İranlılar değil Soğdlulardı (Xinru, 2010: 69). Turfan'da diğer vaha kentlerinde olduğu gibi Soğd diasporası yani yerleşimleri mevcuttu ve bunlar ticaret, ziraat ve el sanatları üretimiyle meşguldüler. Soğdiyanalı tüccarlar, diasporaya mevcut insanlarla iletişim halinde idiler ve kasaba kasaba Doğu Türkistan içerisinde seyahat ederek mal alıyor ve satıyorlardı (Skaff, 2003: 476) Yedinci yüzyılın başlarına tarihlendirilebilen bir Turfan bölgesi dokümanına göre; buradaki toplam tüccarlar arasında Soğdlular, yüzde 82'yi oluşturmaktaydı (Skaff, 2003: 501-502).

Turfan bölgesi kuzeydeki bozkırlara geçiş için de önemli bir güzergâh konumundaydı. Tarihsel olarak yaşanan bir takım süreçler bu coğrafik koşulların etkinliğini artırmıştır. Örneğin, 8. yüzyılın ikinci yarısı Kansu bölgesinin Tibetlilerce işgali sonrası İpek Yolu güzergâhı da bir süreliğine değişmişti. Baykuzu'nun belirttiğine göre; İpek Yolu'nun temel güzergâhı Turfan bölgesindeki Pei-t'ing'den (Beşbalık) Kansu bölgesine, oradan da Çin başkenti Chang-an'a ulaşmaktaydı. Fakat Kansu bölgesi Tibetlilerin eline geçince, İpek Yolu tüccarları başka yollar aramaya çalıştılar. Böylece Kansu'ya gitmemek için Pei-t'ing'den kuzeye doğru çıktılar ve Uygur topraklarına girdikten sonra Çin başkentine gittiler. 781 yılından itibaren bir süre bu yol kullanılmaya başlandı (Baykuzu, 2015: 68).

\section{Karaşar ve Kuça}

Karaşar, Turfan'ın batısında Kuzey İpek yolu rotası üzerinde bulunmaktaydı. Buranın Han zamanından beri Çinlilerce bilinen adı Yen-ch'i idi. Karaşar şehri ana İpek Yolu'nun az kuzeyindeki dağlar içerisinde bulunuyordu. Bu nedenle Karaşar şehrini alabilmek Çin orduları için çok güç olmuştu (Bielenstein, 2005: 299).

Karaşar'ın batısında ve Kuzey İpek Yolu üzerinde bulunan Kuça'nın Çin kaynaklarında Han zamanından itibaren adı Chiu-tz'u'dur (Bielenstein, 2005: 301) Hindistan'da Kral Aşoka'nın (M.Ö 304-232) ülkesinin sınırlarını Kuça'ya kadar genişlettiğinden bahseden kayıtlarda ise ilk kez adına rastlanmaktadır (Baykuzu, 2015: 72).

Kuça'nın ticaret sayesinde elde edindiği sonuçlardan biri de din alanındadır. Baykuzu'nun işaret ettiği üzere; esasen M.Ö. V. yüzyılda Hindistan'da doğan Budizm, Orta Asya coğrafyasına M.S. I. yüzyıldan itibaren girmeye başlamıştır. III. yüzyıla gelindiğinde 
ISSN-2199-353X

\author{
Online only at http://www.cahij.com/
}

Doğu Türkistan coğrafyasının Güney İpek Yolu üzerinde bulunan şehirlerinde parlamaya başlamıştır. Hindistan'dan gelen Budizm, Kuça'da daha çok Hinayana mezhebiyle yayılmış ise de asıl kitlesel Budistleşme Budizm'in Mahayana mezhebiyle olmuştur (Baykuzu, 2007: 196). 3 ve 4. yüzyıla ait Chin Sülalesi tarihinde; kentin içinde bin tane Buda tapınağı ve Stupa kalesi olduğu anlatılmaktadır. Kuça'nın büyük bir ticaret şehri olması nedeniyle, yerli esnaf arasında Buda dininin çok gelişmiş olduğunu bilmekteyiz (Ögel, 2015b: 413-414). ${ }^{9}$ Uhlig'e göre; Tun huang ve Turfan vadisinden farklı olarak Kuça'da Batı ve Güney etkileri çok belirgin olarak görülmekteydi. Burada Hindistan'dan olduğu kadar özellikle İran'dan, yani Sasaniler'den gelen biçimlendirme tarzı da ağırlıktaydı (Uhlig, 2000: 311).

\title{
Hotan
}

Hotan, güney İpek Yolu boyunca seyahat rotasındaki büyük vahalardan biridir. Han zamanından beri Çin kaynaklarındaki adı Yü-t'ien dir (Bielenstein, 2005: 306) Tarım havzasında yer alan Hotan, coğrafik bakış açısıyla en çok destek gören vaha devleti idi. Çünkü Hotan, bereketli lös topraklarının olduğu bir alanda kurulmakla birlikte, büyük iki nehir tarafından da sulanmaktaydı. Üstelik doğudan ve batıdan yasaklayıcı çöllerle çevrili idi, bu da onu büyük ölçekli etnik istilalardan koruyordu (Samolin, 1958: 52). İpek Yolu rotas1 üzerinde bulunan Hotan, Ögel'in belirttiğine göre; türlü milletlerin ticaret kolonilerinden meydana gelmiş; Hint, İran ve Çin kültürlerinin birleşip, kaynaştıkları bir merkez konumunda idi (Ögel, 2015b: 262-263). Yine Hotan, Doğu Türkistan bakımından Budizm'in yoğun yaşandığ 1 yerlerden biri idi. ${ }^{10} \mathrm{Bu}$, Hotan bölgesinin Doğu-Batı ticareti ve en aktif yerlerinden biri olması ve Hindistan'la ilişkili Belh gibi merkezlerle temas kurma kolaylığından kaynaklanmaktaydi.

\footnotetext{
${ }^{9}$ (Kuça) T'ang-şu, K'iu-tse, aynı zamanda K'ü-tse şeklinde de yazılmaktadır. Belirtildiğine göre; Bura başkentinin halkı şarkı söylemeyi ve eğlenmeyi sever. Yazıyı yatay olarak yazarlar. Budisttirler. (Chavannes, 2007: 161). Kaşgar'dan çıkıp Kuça yolu üzerinde yer alan Tumşuk'da Hint paraları bulunmuştur. 1873 yılında İngiliz kaşif ve gezici T.D. Forsyth'nin başkanlığındaki heyet, Tumşuk'da antik harabeler bulmuşlardı. 1895 yılında Swen Hedin, Tumşuk'u ziyaret etti. O burada bir yerleşim yerinin olduğunu kayıt etmekteydi. 1906 yılında Paul Pelliot ve ekibi antik şehir ve çevresinde bölgede kazı yaptılar. Burada 400 den fazla materyal bulundu. Bunlar, 4. Yüzyılın sonu ile 7. Yüzyılın başlarına tarihlendirildiler. Bunların içerisinde 30'dan fazlası Brahmi dilinde yazılmış dokümandı. 10'dan fazlası da Çince idi. 1913 yılında Alman kazı ekibi A.Von.Le Coq başkanlığındaki heyet Tumşuk'daki yerleşim yerini yeniden kazdı. Burada 152 kutu materyal buldu. Bunların içerisinde 10'dan fazla Brahmi dilinde doküman vardı. 1928 yılında Çin-İsveç Bilimsel Araştırmalardan Huang Wenbi, Kuzey batı Xinjiang'da kazılar yapmakta idi, Tumşuk'u da ziyaret ettiler. Burada yaklaşık 7. Yüzyıla tarihlenen mezar yerleri kazıldı ve Brahmi dilinde dökümanlar ile madeni paralar bulundu. 1958 yılında Xinjiang'dan arkeologlar Toqua-sarai bu bölgeyi tekrar kazdılar ve buldukları malzemeler ile dokümanları 4.yüzyılın sonu ile 11. Yüzyılın başlarına tarihlendirdiler. İddiaya göre bu dökümanlar arasında Toharca, Çince, Uygur ve Arapça belgeler bulunmuştu fakat bu belgeler hala yayınlanmadı ( Xinjiang, 2005, s.119-120). Tumşuk, Doğu Türkistan'da Barçuk’un kuzeydoğusunda konumlanmıştır. Han Hanedanlığı döneminde Tumşuk, Yutou krallığı tarafından idare ediliyordu. Görünüşe göre Yutuo, Shule den (Kaşgar'dan) Wensu'ya giden rota üzerinde idi. Günümüzdeki Barcuk alanı burası. Yutuo bağımsız fakat küçük, politik olarak da zayıf bir ülke idi. İki büyük krallık yani Shule ve Kuça arasında konumlanmıştı ve genellikle sonrakine yandaş idi. Sui ve Tang Hanedanlığı döneminde burası hakkında özel ve uzun bir kayıt yoktur (Xinjiang, 2005: 122-123

${ }^{10}$ Vaissiere'nin belirttiğine göre; M.S. 400 yllında Hoten, Mahayanisttir, Bu dönemde ziyaret eden Fa-Hsien'in raporunda bu dini egemenlik tamamıyla tamamlanmıştı. Fakat söylediğine göre Budist yasaları aramak için Batı'ya giden Çinli hacı Zhu Shixing, (M.S. 265-270 Hotan da bir süre kalmış ve burada Prajnaparamita tekstlerini elde etmek için girişimde bulunmuştu. Zhu'nun biyografisine göre buradaki Hinayanist rahipler ona karşı çıkmıştı. Hotan'da Hinayanist rahiplerin Mahayanist rahiplere göre hem sayıları çok fazla hem de çok daha güçlü idiler, üstelik Kral da bunlarla işbirliği, ittifak içinde idi. Bu nedenle onun isteğine engel oldu. Dolayısıyla Zhu Shixing ile Fa- Hsien arasındaki bir zamanda yani M.S. 270-400 y1lları arasında Mahayana Budizmi, Hotan da egemen dini parça haline gelmiş olmalıdır (Vaissiere, 2010: 86).
} 
ISSN-2199-353X

\section{Online only at http://www.cahij.com/}

Hotan, İpekböceği yetiştiriciliği açısından da anlamlı bir tarihe sahiptir. Uhlig'in işaret etiği üzere; British Museum'da, Taklamakan çölünün eski ticaret kenti olan Hotan'ın yüz kilometre kuzey doğusunda bulunan Dandan- Ulik ${ }^{11}$ tapınağına ait "İpek Prensesi” adını taşıyan küçük bir tahta adak levhası vardır. Söylenildiğine göre; Prenses, Çin imparatorunun 420 yıllarında Hotan kralıyla evlendirilen kızıdır ve başındaki büyük topuzun içinde, ipekböceği yumurtaları ile dut ağacı tohumlarını Çin'den kaçırmayı başarmıştır (Uhlig, 2000: 248-249). Bu gelişmeden en büyük kazancı sağlayanlar Tarım havzasındaki vaha kentleri oldu. Bundan sonra İpek yollarının da anlamı değişti ve gittikçe artan ölçülerde üzerinde yer alan kentlerin imalatlarını da taşımak için kullanıldılar (Uhlig, 2000: 256). Yine Hotan güney İpek Yolu rotasındaki Niya'nın ${ }^{12}$ batısında idi.

\section{Kaşgar ve Taşkurgan}

Kaşgar'ın Çin kayıtlarında Han çağından beri ismi Su-le'dir Tarım bölgesinin batı bölümünde bir vahada bulunan Kaşgar, kuzey ya da güney ipek yolundan batıya hareket eden bir kişinin rotasının buluşma yeridir. Bu nedenle Kaşgar iki rota üzerinde de sayılabilir (Bielenstein, 2005: 305). Yani Kaşgar, Asya'nın doğusuyla batısını birbirine bağlayan en stratejik noktadır. Bu yüzden tarihi ve kültürü oldukça eski ve zengindir (Baykuzu, 2015: 7778). Zira Kaşgar Doğu Türkistan'da Budizm'in erken yerleştiği yerlerden biridir. ${ }^{13}$

İpek Yolu güzergâhları bakımından önemli bir diğer bağlantı noktası da Taşkurgan'dır. Tezcan'ın çalışmasında belirttiğine göre; İpek Yolu, Batı ve Doğu olmak üzere başlıca iki ana bölgeye ayrılmakla birlikte, Doğu ile Batı'dan gelen yolların, bugünkü Doğu Türkistan'ın batısında, Pamir eteklerinde bir yerde bulunan Taş-Kurgan'da kesiştiği anlaşılmaktadır. Bu kesişme noktasında, Doğu ve Batı bölgelerinden gelen malların değiş tokuş edildiği anlaşılmaktadır (Tezcan, 2014: 97-98). Stein'in belirttiği üzere; Taşkurgan ile "Stone tower", Ptolemoeus veya Marinus'un tarifiyle aynıdır. Doğal olarak bu yer ticaret değiş tokuşu için oldukça uygun bir yerdedir (Lalitha, 1991: 900).

\footnotetext{
${ }^{11}$ Dandan Ulik Sitesi, çölde Hotan ile Keriya Derya arasındadır. İngiliz arkeolog Stein burada yaptı̆̆ı kazılarda yazma parçaları bulmuştur. Bunların tarihleri 710 ile 790 arasına tarihlenmiştir. Yine burada 760 yılına tarihlenen Çin bakır paraları bulunmuştur. Bu durum buradaki yerleşimlerin 8. Yüzyıl sonuna yani Tang hanedanlığının sonraki dönemine kadar devam ettiğini göstermektedir. Dandan -Ulik yakınlarındaki Ravak Site'de bulunan mabetten geriye kalanlar bu yerleşimin Dandan Ulik’teki ile aynı yapıya ait olduğunu göstermekte fakat buranın son tarihi hakkında kesin bir bilgi verilmemektedir. Khadali sitesi ve Domoko ise, Hotan ve Keriya vahası arasındadır. Burası da Dandan - ulik ile aynıdır. Mazartag'daki gözetleme kulesi Hotan deryanın orta mevkiindedir ve Tang döneminde Tibet saldırılarını karşı inşa edilmiştir. Fakat burası da 8. Yüzyılda Tibetliler tarafından işgal edildi ve uzun süre yaşamadı. Bu ve benzer sitelerin yok oluş tarihleri hakkında Stein açıklamalarına dayanarak bunların birbirine benzer tarihlerde ve Tarim Basin bölgesinin Tang yönetiminden çıktığı döneme denk geldiğini söylemek mümkündür (Hoyanagi, s.95) .

${ }^{12}$ Hansen'in belirttiğine göre; 1901 yılında Aurel Stein, Niya sitesine vardığında onun deve rehberi, üzerinde yazı bulunan iki ahşap parçası vermişti. Bu Stein için bir sürpriz olmuştu. Stein, bunların üzerinde bulunan Khoraşti el yazısını tanımıştı. Khorasti yazısı, üçüncü ve dördüncü yüzyılda Sanskritçe ve Hindistan'la ilişkili yerel dilleri yazmak için kullanmaktaydı. Bu iki dokümandan biri, İpek yolunun kültür, dil ve din konusunda sağladığı geçişi göstermesi bakımından son derece önemliydi (Hansen, 2012: 25).

${ }^{13}$ Kaşgar, M.S. 2. Yüzyılda Budizm'le tanışır. Baktriya bölgesinde devlet kuran Yüeh-ch'ihlerin M.S. 120 dolaylarında hakim oldukları sahayı genişleterek Kaşgar'ın içişlerine müdahale etmeye başlaması, bölgenin Budizm'le tanışmasına neden olmuştur. Kaşgar prensinin tahta çıkarılmasından önce uzun süre rehine olarak kalması, Tarım havzasının bu kısmında Budizm propagandasını yaygınlaştırmıştır (Baykuzu, 2015: 79-80).
} 
ISSN-2199-353X

Online only at http://www.cahij.com/

Çin tarihi bakımından Sui İmparator Yang-ti zamanında (M.S. 605-615), devlet adamı Pei chü'nün, Sui şu da bulunan biyografisinde Batı bölgeleri (Hsi-yü) hakkında bilgi vermektedir. Buna göre; Güney rota, Şanşan ve Hotan üzerinden, Kargalık ve Taşkurgan üzerinden geçilerek Pamir (Tsung-ling) dağları aşılarak, Vahşan vadisi geçilerek, Toharistan (Afganistan) topraklarına girilir ve sonunda Hindistan'a varılırdı (Xinjiang, 2013: 64). Dolayısıyla Taşkurgan'ın önemli bir nokta olduğu açıktır. Lalitha'nın işaret ettiği üzere; Merkezi Asya ile Uzak Batı ve Doğu arasındaki en eski ithalat rotası açısından Taşkurgan'dan açılan yol Kaşgar veya Hotan'a eşit biçimde açıktır ve bu nedenle her iki büyük rotada Türkistan'dan Çin içlerine gitmek için önde gelir (Lalitha, 1991: 900).

Ercilasun'un çalışmasındaki tarifine göre; Pamir üzerinden olan yol iki farklı koldan Kaşgar'a ulaşmaktadır. Kaşgar'ın güneyindeki Taşkurgan'dan çıkan bir yolcu, bugünkü Tacikistan'a girdiğinde yolun iki kola ayrıldığını görür. Bunlardan biri Vahan nehrini takip eder ve Afganistan'a geçer. 7. yüzyılın ilk yarısında bölgeden geçen Çinli rahip Hsüan Tsung, Taşkurgan ile Vahan koridoru arasındaki bölgeyi Bo-mi-luo Vadisi olarak tarif etmiştir. 13. yüzyılda Marco Polo'da Vahan koridorunu kullanarak Kaşgar'a geçmiştir. Yine Sir Aurel Stein, Vahan koridorunun çok eski zamanlardan beri Belh ile Doğu Türkistan arasında önemli bir geçiş noktası olduğunu belirtir (Ercilasun, 2015: 139). Esasen Taşkurgan bulunduğu konum itibarı ile Belh ve Hotan arasındaki ana yollardan biri üzerinde bulunmakta idi. Burası, Belh üzerinden gelen Budizm'in en açık olduğu yerlerden biri olduğu gibi, tarihi İpek Yolu'nun kullandığı en önemli güzergâhlar arasında yer almaktaydı (Ercilasun, 2015: 139).

\section{Baktriya}

Bugünkü Tacikistan topraklarına denk gelen, Çince kaynaklarda ise Ta-hsia ${ }^{14}$ olarak geçen tarih araştırmaları bakımından ise Toharistan veya Baktriya olarak tarif edilen bölgedir. Coğrafik olarak burası Bedehşan ve batısındaki bölgedir. Bugün; Tacikistan, Afganistan ve Özbekistan topraklarının bir kısmını kapsamaktadır. İlk Çince kaynaklarda genellikle büyük Yüe-çi kavmiyle bir arada anılır (Ercilasun, 2015: 140). M.Ö. I. yüzyılda Baktriya bölgesinde bir devlet kuran Yüeh-chih'lerin devleti M.S. 3. yüzyılın ortalarına kadar varlığına devam etmiştir. Tarihte Kuşhan olarak adlandırılan bu devlet, sadece Doğu -Batı ticareti değil, Hindistan ve Güney Doğu Asya'ya kadar ulaşan ticari ağın önemli bir parçası olmuştur.

Zira Vaissiere'ye göre; Milattan sonraki ilk yüzyıllarda temel ticari rotanın Çin'den başlayarak batıya doğru yol aldığını ve buradan da Güney Soğdiyana’yı geçerek Hindistan’a vardığını söyleyebiliriz. Pamir Dağları ve Hindukuş yolları vasıtasıyla Baktriya bölgesi de bu ticaretin içerisinde bulunmaktaydı ve bundan faydalanmaktaydı. Klasik Batı kaynaklarının, 2 - 3. yüzyıla dair İpek Yolu ticareti hakkında verdiği bilgilere göre; Çin ve Roma imparatorluğu arasında ipek temeline dayanarak yapılan büyük ölçekli ticaret, başlıca olarak

\footnotetext{
${ }^{14}$ Ögel'e göre; Ta-Hsia deyimi Çincede büyük Hsia demektir. Bu sözün kökleri de ilk Çin sülalesi olan Hsia sülalesine kadar gitmektedir. Bundan dolayı mitolojik bir deyimken daha sonraları bu ad; kuzeyde, batıda ve güneyde, çok uzaklarda bulunan ve Çinlilerce iyi tanınmayan bir yer adı olarak kullanılmaya başlanmıştır. Zamanla Çincedeki bu deyimin anlamı değişmiş ve "uzakların uzağı, ötelerin ötesi” manasında kullanılmaya başlanmıştır. Geçmişte Çinli elçi Chang Ch'ien, Batı Türkistan ve Baktriya'ya geldiği zaman gezisinin sonuna gelmiş bulunuyordu. Bundan dolayı Baktriya'ya bu mitolojik adı yani Ta-Hsia adını verdi (Ögel, 2015a: 136).
} 
ISSN-2199-353X

Online only at http://www.cahij.com/

Baktriya'lı ve Hintlilerin aracılığıyla gerçekleşmekteydi (Vaissiere, 2005: 35-36). Sonraki tarihi süreçte, Akhun ve Gök Türk döneminde de Baktriya bölgesi bu ticari ehemmiyeti korumuştur, fakat İpek Yolu ticareti açısından, başka bölgelerin önemini daha da arttırdığını söylemek mümkündür.

\section{Maveraünnehir}

İpek Yolu güzergâhları içerisinde en önemli yerlerden biri Soğdiyana bölgesi olarak da tarif edilen, Batı Türkistan sahası içerisinde bulunan Amu-Derya ve Sır-Derya nehirleri arasındaki bölgedir. $\mathrm{Bu}$ bölge hem bulunduğu konumu hem de yerli mahir tüccarları nedeniyle İpek Yolu tarihi bakımından önemlidir.

Tarihte, Soğdiana/ es-Suğd ifadesi, Semerkant'ın üstünlüğünü kabul eden bağımsız prenslikler konfederasyonunu ifade etmektedir (Taşağıl, 2009: 349-350) Bu bölgenin en önemli ve ünlü Soğd şehirleri; Semerkand ve Buharadır. Politik olarak aslında bu vaha şehirleri aynı vadi içerisinde yer almalarına rağmen birbirinden bağımsız olarak var olmuşlardır ve 8. yüzyılda Araplar egemen olana kadar da bu durum böyle devam etmiştir. Buralar, İslam orduları gelmeden önce genel olarak göçebe kabilelerin gevşek yönetimi altında kalmışlardı (Skaff, 2003: 475-476). ${ }^{15}$ Samaniler döneminde Buhara'nın başkent olduğu dönemde bile, gerek nüfus gerekse büyüklük bakımından Semerkant, Maveraünnehir'in birinci şehri olmuştur (Barthold, 1990: 88).

Esasen Soğdiyana bölgesi, sadece Çin ile Batı Asya ve Avrupa’yı birbirine bağlayan Doğu-Batı ticaret yolunun stratejik bir yerinde olmakla kalmamış, güneyde Hindistan'a, Kuzeyde de Kuzey Asya'nın bozkırlarına bağlanan, dolayısıyla güney ve kuzeyi birbirine bağlayan ulaşım açısından da önemli bir yere sahip olmuştur (Mori, 1984: 340). Bu nedenle Semerkant şehrinin önemi de coğrafi konum olarak; Hindistan'dan Belh üzerinden gelen, İran'dan Merv üzerinden gelen ve Türk egemenliği altındaki bölgelerden gelen tüm ticaret yollarının kesiştiği bir noktada bulunması ile açıklanabilir (Barthold, 1990: 88)

Soğdiyana bölgesi içerisinde İpek yolu ticareti sayesinde gelişen ve büyüyen yeni kent merkezleri de ortaya çıkmıştır. ${ }^{16}$ Yine bazı bölgeleri iktisaden bura ile bağlantılı görmemize neden olacak tarihi gelişmeler yaşanmıştır. Bu merkezlerden biri de Suyab'dır.

\footnotetext{
15 7. yüzyıl Çin kaynağı Hsüan Tsung'un seyahatnamesinde anlattığına göre; Semerkant: "Sa-mo-chien bölgesi çevresel olarak bin altı yüz-bin yedi yüz li kadardır. Doğudan batıya genişlemiştir [uzamıştır], ancak kuzeyden güneye daralmıştır. Bölgenin başkentinin çevresi 20 li'den fazladır. [Bölgenin çevresi sağlam surlarla çevrilidir;] [stratejik bir noktada] çetin bir arazidir ve [bundan dolayı] kalabalık bir nüfus yerleşmesi vardır. Bölge Hu halklarının ortasındadır [ve kültürel bir merkezidir]. Yaşam tarzı ve davranışlar açısından da çevredeki [uzak ve yakın] halklara örnek olmaktadırlar" (Ergüven, 2011: s.49-50)

${ }^{16}$ Bunlardan biri de Pencikent’tir. Günümüz Tacikistan'ında; Zerefşan dağları ile Türkistan dağları arasından aktığını bildiğimiz Zerefşan Nehri, burada oluşturmuş olduğu vadi ile doğu-batı yönlü bir geçiş sağlamaktadır. Pencikent ise bu vadinin batı ucunda kurulmuştur (Ercilasun, 2015: 137). Arkeolojik bir site olan Pencikent, Semerkant'1n 60km doğusunda konumlanmaktadır. Burası eski Soğdiyana'nın merkez bölgelerinden biridir. Buraya ait duvar boyaları ve heykelleri beşinci ve sekizinci yüzyıl arasına tarihlendirilir (Marshak ve Raspopova, 1994: 187-207) 5 ve 8. yüzyıl arasına tarihlendirilen Pencikent harabeleri arkeolojik açıdan kıymetlidir. Burada 8. yüzyılın başından kalmış Budizm ile ilgili duvar resimleri ve diğer eşyalar bulunmaktadır. Bunlar, şehrin Budizm'in Türkistan'da yayılması hususunda önemli yerlerden biri olduğunu göstermektedir (Ercilasun, 2015: 150-151). Hansen'e göre; Pencikent, İpek yolunun en önemli arkeolojik yerleşim yeridir (Hansen, 2012: 121) Sovyetler birliği döneminde 1947 yılında yapılan arkeolojik kazı buluntuları Hermitaje müzesindedir.
} 
ISSN-2199-353X

\author{
Online only at http://www.cahij.com/
}

\title{
Suyab
}

İpek Yolu tarihi bakımından önemli merkezlerden biri de Suyab'dır. Kırilen'in belirttiği üzere; Suyab, Tanrı dağlarının batısındaki en büyük kentlerden biriydi. Tanrı dağlarının iki yanından gelen İpek Yolu'nun her iki güzergâhı bu bölgede buluşmaktaydı (K1rilen, 2015: 57).

Sümer'in belirttiği üzere; eski araştırıcılar Sûyâb'ın Çin kaynaklarındaki Soey-şe (SuŞe) olduğunu ve buranın günümüzdeki Tokmak'ın yerinde bulunduğunu iddia etmişlerdi. Minorsky ise çalışmasında Sûyâb'ı, Çu ırmağının orta yatağının az kuzey doğusunda aramış, Tokmak'ın da eski Tümket olduğuna ihtimal vermişti. Ancak Minorsky çok daha sonra «Addenda to The Hudûd al-'Âlam» de Arkeolog A.N. Bernstam'ın, Sûyâb'1, Kemin irmağ1 kıyısını da Kemin'in Çu'ya karıştığı yerin yukarısında gösterdiğini söylemiştir (Sümer, 2006: 74). Clauson'a göre; tarihi kaynakların anlattığı meşhur şehir Suyab, arkeologların da açıkça gösterdiği ve Clauson'un kesin kanaatine göre Ak Beşim'dir. Burası ilk olarak, büyük ihtimalle tüccarların küçük toplulukları tarafından iskan edilmişti, bunlar da muhtemelen Soğdlardı. Bu hadiseler beşinci veya altıncı yüzyılda gerçekleşti. Zamanla şehir büyüdü ve etrafi kuvvetli savunma duvarlarıyla çevrildi. Burada çeşitli dini inanışlara ait yapılar da ortaya çıktı (Clauson, 1961: 4). Ak-besim (Suyab) yapılan kazılarda, sekizinci yüzyıla ait Soğd ve Türkiş madeni paraları ile Heraklios (M.S. 611-641) ve Constantinus (M.S. 641-668) dönemine ait Roma paraları bulunmuştur. $\mathrm{Bu}$ da Soğd ticaretinin Doğu ve Batı arasındaki coğrafi genişliğini göstermesi bakımından önemlidir (Walter, 2006: 18). Tarihi boyunca Suyab şehri, birden fazla defa istilaya ve yağmaya uğradı. Yaklaşık olarak da onuncu yüzyılda, Balasagun'un inşa edildiği dönemlerde varlığına son verildi (Clauson, 1961: 4). ${ }^{17}$

\section{Sonuç}

Doğu ve Batı dünyası arasında ticari ilişkilerin geçmişi çok daha eski olmakla birlikte, tarihi hadiselerin bir neticesi olarak açıldığı değerlendirilen İpek Yolu, esasen Hun ve Han Devletleri arasındaki siyasi ve askeri çekişmenin bir neticesi olarak hayat bulmuştu. $\mathrm{O}$ tarihlerde, gerek siyasi ve gerekse coğrafik koşulların bir sonucu olarak Çin için dış dünyaya açılan tek kapı "Batı kapısı" idi. Kısaca Kansu bölgesi olarak bildiğimiz bu alan ise, çok eski devirlerden itibaren olduğu gibi Hun döneminde de yoğun Türk etkinliğinin bulunduğu bir

Tarihte Pencikent, 722 yılında Arap ordularının eline geçmiş ve bu durum 740 yılında tekrarlanmıştır. Bu nedenle şehir, 770 780 yılları arasında tamamen terk edilmiştir. Burada geçmişte beş bin ile yedi arasında yerleşik yaşamaktaydı. Şehir beşinci yüzyıla tarihlenen duvarlarla çevriliydi. Şehirde pek çok cadde, geçit, iki bazars, iki tapınak bulunmaktaydı. Bunlardan bir tanesi ateş altarı bulunan, diğeri birbirinden farklı on tane tanrıyı barındıran bir tapınaktı. Bu tapınak bir odası ve girişten bağımsız Hint tanrısı Şiva'ya ev sahipliği yapıyordu. Ticari maksatlı tahıl ambarları ve bazarlar, Pencikent ticareti hakkında fikir vermektedir (Hansen, 2012: 121). Pencikent kazıları açıkça göstermektedir ki 8. yüzyılın ilk on yıllarında, Soğdiayana'daki Arap istilaları ile pek çok şehir zora düşmüş ve pek çok sayıda Soğdlu buralardan göç etmiştir. Bunların çoğu; Merv, Nişabur, Bagdad, ve Samarra gibi kentlere gitmişti (Krıppes, 1991: s.72).

${ }^{17}$ Kırılen'in belirttiği üzere; Bugünkü Akbeşim ya da Suyab, Turges Suyab olarak da bilinmektedir. (Çince Suiye) . Bugün Kırgızistan'ın başkenti Bişkek'in 60 km kuzey doğusunda, Tokmak'ın altı kilometre güneydoğusunda Çuy vadisinde yer almaktadır. Yedinci yüzyılda bu bölgenin bütünüyle Gök Türk egemenliği altında olduğu, Batı Gök Türk merkezinin de burada olduğu bilinmektedir. 7. yüzyılın ilk yarısında buraya gelen Çinli Budist Hacı Hsüan Tsung'ın seyahatnamesinde yer almamakla birlikte, "Hatıratında" anlattığı, Batı Gök Türk Kağanı ile karşılaşması da burada gerçekleşmiştir (Kırilen, 2015: 57). Sümer'e göre; Türk tarihinde, Türgiş boyuna mensup ilk kağanlar şehir hayatına ilgi göstermişler ve son Türgiş kağanları da Suyab şehrinde oturarak devletlerini buradan idare etmeye başlamışlardır (Sümer, 2006: 20). 
ISSN-2199-353X

Online only at http://www.cahij.com/

saha idi. Üstelik Kansu'nun hemen yanında yer alan ve ticari yolların en önemli güzergâhlarından biri olan Doğu Türkistan sahası da Hun hakimiyeti altındaydı. Dolayısıyla, Han ve Hun devletleri arasındaki mücadele, Han devletinin dışarıya açılmak ve Batı bölgelerinde bulunan halkları ve devletleri kendi hegomanyası altına almak çabası, dolaylı da olsa bahsedilen bu ticari yolların gelişimi gibi bir sonuç doğurmuştu. Esas itibariyle Kansu bölgesinden sonra iki ana kola ayrılan yollar, büyük ölçüde çöllerle kaplı coğrafik koşulların bir neticesi olarak Kuzey ve Güney rotası olarak devam etmektedir. Bu rotaların tercih edilmesi ve kullanılması durumu, tarihi sürecin neden olduğu coğrafik ve siyasi koşullarla bağlantılı olmuştur. Su kaynaklarının durumu ve çölleşme bazı durakların yok olmasına veya yer değiştirmesine neden olmuştur. Yine mevcut siyasal durum ve yolların güvenliği gibi konular da rotaların tercih edilmesinde etkili olmuştur.

İpek Yolu iktisadiyatının gelişmesi, büyük çöl sahasının hemen yanında bulunan Doğu Türkistan bölgesinin ve pek çok kentinin bu ticaretten istifade etme imkanına kavuşmasına neden olmuştur. Doğal olarak; Luo-lan bölgesi, Hami, Turfan, Karaşar, Kuça, Hotan, Yarkent, Kaşgar gibi şehirler büyümüştür. Yine Doğulu ve Batılı tüccarların yanında Hint kökenli tüccarların da varlığıyla Doğu Türkistan sahası kültürel anlamda da zenginlik kazanmıştır. Bu kentler ve bu kentlerin etrafında ortaya çıkan yeni yerleşim yerleri ise zengin kültürel unsurlar barındırmıştır.

Coğrafi koşulların sağladığı stratejik önem nedeniyle bazı bölgelerin İpek Yolu güzergâhları arasında özel bir yere sahip olduğu anlaşılmaktadır. Bununla ilgili olarak İpek Yolu rotalarının temas ettiği en önemli noktalardan biri de Batı Türkistan yani Maveraünnehir sahası olmuştur. Özellikle Semerkant ve Buhara'da kesişen ticari rotalar hem bu kentleri hem de bu kentlerin sakinleri olan Soğdları, İpek yolunun en önemli unsurlarından biri haline getirmiştir. Yine bu bölgeyle çok yakın bir konumda bulunan Baktriya bölgesi de, İpek Yolu'nun erken dönemlerinden itibaren, bu ticari ağın en önemli merkezlerden biri olmuştur. Hem Maveraünnehir hem de Baktriya bölgesi sadece Doğu-Batı güzergâhlarının değil, Kuzey-Güney doğrultusundaki ticari yolların da kesiştiği önemli bir alandır. Bu nedenle bahsedilen coğrafi sahaların yakınlarında da önemli ticari ve kültürel merkezler ortaya çıkmıştır.

\section{KAYNAKÇA}

BARTHOLD, V. V., Mogol İstilâsına Kadar Türkistan, Haz. Hakkı Dursun Yıldız, TTK Yayınları, Ankara 1990.

BAYKUZU, Tilla Deniz, “Turfan'dan Kaşgar’a İpek Yolu Üzerindeki Vaha Şehirleri”, İpek Yolu, TKHV. İstanbul 2015, s.59-85.

BAYKUZU, Tilla Deniz, “V. Yüzyılda Hunlar ve Budizm”, Atatürk Üniversitesi Türkiyat Araştırmaları Enstitüsü Dergisi, S.34, Erzurum 2007.

BECKWITH, Christopher I., İpek Yolu Imparatorlukları, ODTÜ Yayıncılık, Ankara 2011. 
ISSN-2199-353X

Online only at http://www.cahij.com/

BIELENSTEIN, Hans, Diplomacy and Trade In The Chinese World 589-1276, Handbook of Oriental Studies, Section Four China, Brill, Leiden-Boston 2005.

CLAUSON, Gerard, "Ak Beshim- Suyab", The Journal of the Royal Asiatic Society of Great Britain and Ireland, No:1/2, (1961), s.1-13.

COSMO, N.D., "Hun İmparatorluğunun Kuruluşu ve Yükselişiı", Türkler Ansiklopedisi, C.1, Yeni Türkiye Yayınları, Ankara 2002, s.709-719.

CHAVANNES, Edouard, Çin Kaynaklarına Göre Batı Türkleri, Çev. Mustafa Koç, Selenge Yayınları, İstanbul 2007.

EBERHARD, Wolfram, Çin Tarihi, TTK Yayınları, Ankara 2007.

EKREM, Nuraniye H. “Chang Ch'ien'in Seyahat Raporuna Göre Hun Döneminde Orta Asya”. Modern Türklük Araştırmaları Dergisi, C.9, S.2, (2012), s.7-51.

ENOKI, Kazuo, "The Location of the Capital of Lou-lan and the date Khorasti Inscriptions", Toyo Bunko, (1963), s.125-171.

ERCILLASUN, Konuralp, "Eski ve Orta Çağlarda Tacikistan Coğrafyası ve İpek Yolu”, İpek Yolu, Ed. Ahmet Taşağıl, TKHV, İstanbul 2015.

ERGÜVEN, İsmail Hakkı, Hsüan-Tsang'ın Seyahatnamesi (7. Yüzyıl) Metin Çevirisi ve Değerlendirme), Çanakkale On Sekiz Mart Üni. Sosyal Bilimler Enstitüsü Yayımlanmamış Yüksek Lisans Tezi, Çanakkale 2011.

GUANGDA, Zhang - Rong Xianjiang, “A Concise of the Turfan Oasis and Its Exploration”, Asia Major, Th1rd Series, Vol. 11, No.2 (1998), s.13-36.

GUMILEV, Lev Nikolayeviç, Eski Türkler, çev. Ahsen Batur, Selenge Yayınları, İstanbul 2004.

GUMILEV, L.N., Hunlar, Çev. Ahsen Batur, Selenge Yayınları, İstanbul, 2013.

HANSEN, Valerie, Silk Road, Oxford Unıversity Press. New York, 2012.

HOYANAGI, Mutsumi, "Natural Changes of the Region along the Old Silk Road In the Tarim Basin in Historical Times", Toyo Bunko, s.85-110.

KIRILEN, Gürhan, Budizm ve Orta Asya: Xuan Zang Seyahatnamesi, Gece Kitaplığ1 Yayınlar1, Ankara 2015.

KRIPPERS, Karl, "Sociolinguistic Notes on the Turficication of the Soğdians", Central Asiatic Journal, Vol. 35, (1991) ,s.67-80.

LALITHA V., "The Silk Route”, Proceeding of the Indian History Congress, Vol. 52 (1991), s.894-902.

MARSHAK, B.I. Marshak-V.I. Raspopova, "Worshipers From the Northern Shrine of Temple II, Panjikent”, Bulletin of the Asia Institute, New Series, Vol. 8, The Archeology and Art of Central Asia Studies From the Former Soviet Union (1994), s.187-207. 
ISSN-2199-353X

Online only at http://www.cahij.com/

MORİ, Masao, “Soğdluların Orta-Asya'daki Faaliyetleri”, Belleten, 47/185, (1984), s.339351.

ÖGEL, Bahaeddin, Büyük Hun Imparatorluğu Tarihi, Cilt: 1,TTK Yayınları, Ankara 2015.

ÖGEL, Bahaeddin, Büyük Hun İmparatorluğu Tarihi, Cilt:2, TTK. Yayınları, Ankara 2015.

PULLEYBLANK Edward G., "Why Tocharians". Journal of Indo-European Studies, 23, (1995), s.415-430.

ROUX, Jean Paul, Türklerin Tarihi, Pasifik'ten Akdeniz'e 2000 Yıl, çev. Aykut Kazancıgil Lale Arslan-Özcan, Kabalcı Yayınları, İstanbul 2007.

SAMOLIN, W., "Ethnographic Aspects of The Archeology of The Tarım Basın" ,Central Asiatic Journal, Vol. 4, No.1, (1958),s.45-67.

SHIRATORI, Kurakichi, "On the Ts'ung-ling Traffic Route Described by C. Ptolemaueus", Toyo Bunko, (1957), s.1-34.

SHIRATORI, Kurakichi, "On the Territory of the Hsiung-nu Prince Hsiu-t'u Wang and His Metal Statues for Heaven -vorship”, Toyo Bunko, (1930), s.1-77.

SKAFF, Jonathan Karam, "The Soğdian Trade Diaspora in East Turkestan During The Seventh and Eighth Centuries", Journal of The Economic and Social History of The Orient, Vol 46/ Part4/ (2003), s.481-513.

STEIN, Aurel, "The Desert Crossing of Hsüan -Tsang, 630 A.D." The Geographical Journal, Vol. 54, No.5 (Nov. 1919),s.265-277.

SÜMER, Faruk, Eski Türklerde Şehircilik, TTK Yayınları, Ankara 2006.

TAŞAĞIL, Ahmet, “Soğd”, TDV İslam Ansiklopedisi, C. XXXVII, İstanbul 2009, s.348-349.

TEZCAN, Mehmet, “İpek Yolu'nun İran Güzergâhı Ve İpek Yolu Ticaretine İran Engellemesi”, Uluslararası Türkçe Edebiyat Kültür Eğitim Dergisi, Say1: 3/1 2014, s.96-123.

UHLİG, Helmut, İpek Yolu Çin ve Roma Arasında Eski Dünya Kültürü, Okyanus Yayınları, İstanbul 2000.

VAISSIERE, Etienne De la, Soğdian Traders, Trans. James Ward, Ed. Denis Sinor- Nicola Di Cosmo, Handbook of Oriental Studies- Section Eight Central Asia, Brill Leiden-Boston 2005.

VAISSIERE, Etienne De la, "Buddhism and Early Khotanese Chronology; A Note on the "Prophecy of the Li Country", Bulletin of The Asia Institute, New Series, Vol. 24 (2010), s.85-87.

WALTER, Marika Namba, Soğdians and Buddhism, Sino-Platonic Papers, Ed. Victor H. Mair, University of Pennsylvania, 2006.

XINJIANG, Rong, "The Name of So-called "Tumshuqese" Languege", Bulletin of the Asia Institute, New series, Vol.19, İranian and Zoroastrian Studies in Honor of Prods Oktor Skjaervo (2005), s.119-127. 
CAPPADOCIA JOURNAL OF HISTORY AND SOCIAL SCIENCES VOL.17-OCTOBER 2021 ISSN-2199-353X

Online only at http://www.cahij.com/

XINJIANG, Rong, Eighteeen Lectures On Dunhuang, Trans. Imre Galambos, Brill-Leiden 2013.

XINRU Liu, The Silk Road in World History, Oxford University Press, 2010. 